\title{
Probiotics in neonatology: can it be adopted as a standard of care?
}

\author{
Kamal Arora $^{1}$, Deepinder Kaur ${ }^{2}$, Rajoo Singh Chhina ${ }^{3}$ \\ Department of Paediatrics ${ }^{1}$, Department of Microbiology'2, Department of Gastroenterology ${ }^{3}$ \\ Dayanand Medical College and Hospital, Ludhiana, India
}

\begin{abstract}
Probiotics are micro-organisms that confer health benefits to the host. There is a growing body of evidence documenting the immune-modulatory ability of probiotic bacteria. The need for probiotic formulations has been appreciated for the health benefits in "topping up your good bacteria" or indeed in an attempt to normalise the dysbiotic microbiota associated with immunopathology. This review will focus on the use of probiotics in clinical practice, particularly related to neonatal practice, including explanations of what they are and how they work. Evidence for the health benefits of consuming probiotic bacteria are examined in several clinical conditions. Lastly we have tried to solve the debated question that "should probiotics be used as standard of care in neonatal practice?"
\end{abstract}

\section{Key Points}

1. Probiotics are enterally administered live "good' micro-organisms that colonise the gastrointestinal tract to modulate the functions of the innate microbial community and immune system.

2. This may result in significant health benefits; for example enteral probiotic supplementation significantly reduces both severe necrotising enterocolitis and all-cause mortality in preterm infants.

3. There is a debate on routine enteral probiotic supplementation for all preterm infants. Others advise caution pending results from large clinical trials designed to address issues regarding safety and efficacy in the smallest, most vulnerable newborn population.

4. Probiotics may also reduce atopic eczema in high-risk infants when administered to the mother during pregnancy and to the infant post-natally and improve feeding tolerance in neonates.

\section{INTRODUCTION}

Probiotics are used extensively in therapeutic preparations, added to foods and have a major influence on gastrointestinal flora. They are defined as live microorganisms, which when administered in adequate amounts, confer health benefits to the host. ${ }^{1}$ A probiotic micro-organism selected for use in humans should ideally be: a micro-organism of human origin, non-pathogenic, resistant to destruction by technical processing and gastrointestinal tract (GIT) secretions, able to colonise the GIT, capable of producing antimicrobial substances, modulating immune responses and influencing human metabolic activities. ${ }^{2}$ It should be unlikely to develop

\section{Corresponding Author :}

Dr Kamal Arora

Assistant Professor

Dayanand Medical College and Hospital

Ludhiana (Punjab)

Email: dockamalpaeds@yahoo.com resistance to commonly used antibiotics. ${ }^{3}$ The ability of supplemental probiotics to colonise the human GIT has been demonstrated in clinical studies. ${ }^{4-6}$ It is hypothesised that probiotics may alter the microbial community in the digestive tract to mimic the 'healthy' GIT microbiome through the same mechanisms of action as the host's original microflora. ${ }^{7}$

At birth, an infant's gastrointestinal tract is sterile. Colonization of the gastrointestinal tract starts immediately after birth with the initiation of enteral feedings and is well established within the first few days of life. ${ }^{8}$ In breastfed infants, Bifidobacterium and Lactobacillus predominate, with other enteric organisms being present less frequently. ${ }^{9-13}$ This is not the case for formula fed infants. In these infants, coliforms, Enterococci, and Bacteroides predominately colonize the intestinal tract. Preterm infants are particularly susceptible to abnormal colonization. A combination of antibiotic use, delayed initiation of enteral feedings, and exposure to the unusual microorganisms that populate the nursery intensive care unit (NICU) may lead to 
abnormal patterns of colonization. Feeding oral probiotic bacteria may be an effective way to change this pattern of colonization.

Probiotics are marketed in several countries and widely used by pediatric health care providers. Although probiotics can be helpful for specific disorders, they have been broadly prescribed for disorders without clear evidence to support their use. We have reviewed the evidence of its use in various pediatric disorders.

\section{MECHANISM OF BENEFIT}

The American Academy of Pediatrics Committee on Nutrition defined probiotics as 'microbes that generate small molecular metabolic by-products that exert beneficial regulatory influence on host biological functions and may function as immuno-modulators' ${ }^{14-16}$

Probiotics have varied mechanisms through which it confers benefit. The mechanisms of benefits include modification of the gut flora, competitive adherence to the mucus and the epithelium, strengthening of the gut epithelial barrier, and modulation of the immune system (Table I). ${ }^{17}$

Probiotics have been reported to be beneficial in a wide spectrum of conditions ranging from antibioticassociated diarrhea (AAD), irritable bowel syndrome

Table I

Postulated mechanism of action of probiotics ${ }^{17}$

\begin{tabular}{|c|c|}
\hline Mechanism & Benefit \\
\hline $\begin{array}{ll}\text { a. } & \text { Reduction of mucosal } \\
\text { permeability } \\
\text { b. Strengthening of intestinal } \\
\text { tight junctions }\end{array}$ & $\begin{array}{l}\text { Maintains mucosal } \\
\text { barrier integrity }\end{array}$ \\
\hline $\begin{array}{l}\text { a. Modulation of microflora } \\
\text { growth and adherence } \\
\text { b. Reduction of } \\
\text { intraluminal pH } \\
\text { c. Competitive exclusion } \\
\text { of pathogenic bacteria } \\
\text { from binding sites }\end{array}$ & $\begin{array}{l}\text { Regulation of } \\
\text { appropriate } \\
\text { bacterial } \\
\text { colonisation }\end{array}$ \\
\hline $\begin{array}{l}\text { a. Enhanced mucosal } \\
\text { IgA response } \\
\text { b. Production of short- } \\
\text { chain fatty acids }\end{array}$ & $\begin{array}{l}\text { Activation of general } \\
\text { intestinal immune defense }\end{array}$ \\
\hline $\begin{array}{l}\text { a. Increased T cell production } \\
\text { of cytokines } \\
\text { b. Increased production of } \\
\text { anti-inflammatory cytokines }\end{array}$ & $\begin{array}{l}\text { Modulation of } \\
\text { intestinal } \\
\text { inflammation }\end{array}$ \\
\hline
\end{tabular}

(IBS), and travellers diarrhoea to dental caries, ulcers due to Helicobacter pylori, hepatic encephalopathy, and neonatal necrotizing enterocolitis (NEC).

\section{THE HUMAN INTESTINAL MICROBIOME}

The mature human GIT microbial community encompasses several hundred species of microorganisms, which perform vital functions, including digestion of nutrients, regulation of fat storage, metabolism of endogenous and exogenous compounds and immuneregulation plus limiting colonisation with potentially pathogenic microbes. ${ }^{18-21}$ Term infants acquire their intestinal microbial community from the birth canal and close parental contact. ${ }^{13,22,23}$ Failure to establish a normally functioning IM is associated with disease locally (inflammatory bowel disease) and distally (allergic disease) ${ }^{24,25}$ Preterm infants may develop a dysfunctional gut microbiome as they preferentially acquire colonising bacteria from the intensive care environment. ${ }^{26}$ The process may be adversely affected by mode of delivery, administration of antibiotics and prolonged hospitalisation. ${ }^{27-30}$ This leads to delayed colonisation with healthy commensals (e.g. Bifidobacterium and Lactobacillus species (spp) and increased colonisation with pathogenic organisms.

As postulated in Table I, there is evidence that probiotics and their by-products exert these effects both locally within the GIT and remotely in tissues, such as the lung and brain. For example, animal models show that probiotics have immuno-modulatory effects on mediators implicated in injury to the nervous system (e.g. brain-derived neurotrophic factor, interleukin-10, interferon- $\gamma($ IFN- $\gamma$ ), etc.). In these studies, the probioticinduced immuno-modulation improved neurological function, including memory, stress response behaviours and peripheral nervous system reflexes. ${ }^{31}$

Probiotic effects on immune system responses, with associated improved clinical outcomes, have been reported in studies of pregnant women and their infants. These include reduced breast milk tumour necrosis factor- $\alpha$ and inflammatory cells from mothers who received Lactobacillus casei, with decreased gastrointestinal disturbances in the infants. ${ }^{32}$ In an Australian study, women who received pre- and post-natal probiotics had increased levels of breast milk immunoglobulin A ( $\operatorname{Ig} \mathrm{A})$ and their infants had increased blood levels of IFN- $\gamma .{ }^{33}$ Therefore, there is evidence that probiotics administered pre-and/or postnatally can influence the developing 
immune system. The effects of probiotics may be enhanced by the addition of synergistic substances, such as oligosaccharides (prebiotics) or lactoferrin (an ironbinding protein). ${ }^{34}$

\section{PROBIOTICS AND PRETERM INFANTS}

Recent meta-analyses ${ }^{35,36}$ and systematic reviews ${ }^{37,38}$ demonstrate that probiotic supplementation in preterm infants reduces the incidence of significant NEC and allcause mortality, with a relative risk of $0.35(95 \%$ confidence interval (CI) $0.24,0.52$ ) for NEC and 0.40 (95\% CI 0.27, 0.60) for all-cause mortality in the Cochrane database review. ${ }^{39-41}$ (Table II) NEC-affected infants have reduced microbial diversity in their GIT compared with controls, which may limit the ability of their microbiome to perform its important immunoprotective functions. Supplemental probiotic microbes may assist the innate microflora with these functions. Other reported positive effects of probiotics in preterm infants include: improved GIT motility and feeding tolerance, reduction in days of hospitalization, improved weight gain, intestinal colonisation with probiotic organisms and favourably altered immune responses in the probiotic versus placebo group. ${ }^{42-44}$ In 2011, Manzoni et al, who previously reported decreased fungal colonisation in preterm infants treated with Lactobacillus rhamnosus GG(LGG), concluded that routine use of LGG to be "microbiologically safe and clinically well tolerated' ${ }^{45}$

Bifidobacterium and Lactobacillus spp. are the most studied probiotic organisms in neonates to date, and one systematic review suggested that the best clinical outcomes are achieved with combinations of probiotic organisms, rather than a single strain.

Current evidence on the effects of probiotic supplementation on late-onset sepsis, weight gain or neuro-developmental outcome in preterm infants is not supportive for routine use. Results from ongoing large clinical trials, including ProPrems ${ }^{46}$ in Australia and New Zealand, and PiPs (Probiotics in Preterm Infants Study) in the United Kingdom, are awaited to determine further benefits of probiotic supplementation in this vulnerable population (Table III). Evidence-based guidelines for the use of probiotics in preterm neonates have been recently published. ${ }^{47}$

\section{PROBIOTICS AND TERM INFANTS}

Studies of probiotic effects in term infants have focused on allergic diseases, which result from dysfunction of immune regulation. ${ }^{48}$ Children with abnormal perinatal intestinal colonisation are at increased risk of developing allergic diseases, and probiotics can reduce this risk by regulating immune mediators, such as IgA. ${ }^{49,50}$ Some studies have demonstrated that administration of probiotics to pregnant women and/or their infants prevented allergic diseases, particularly infants considered at high risk of developing these conditions. ${ }^{51}$

The Cochrane review ${ }^{52}$ reported an inconsistent effect of probiotics in atopic eczema and concluded that 'There is insufficient evidence to recommend the addition of probiotics to infant feeds for prevention of allergic disease or food hypersensitivity'. Furthermore, there is debate regarding the best timing of pro-biotic administration to prevent or reduce allergic diseases. Supplementation appears to be most beneficial if commenced antenatally and continued postnatally.

\section{EVIDENCE OF PROBIOTICS USE IN NEONATOLOGY}

Evidence from a recent updated systematic review ${ }^{35-38}$ and conclusive meta-analysis of randomized controlled trials (RCTs) indicates the significant benefits of probiotic supplementation in preventing all cause mortality and definite (Stage II) NEC with no significant adverse effects in preterm neonates. [All cause mortality: risk ratio 0.42, $95 \%$ confidence interval $(\mathrm{CI}) 0.29-0.62, \mathrm{p}<0.00001$; definite NEC: risk ratio $0.35,95 \%$ CI $0.23-0.55$, $\mathrm{p}<0.00001]^{35}$ Given the precision of these results, an almost insignificant role of the play of chance alone, and the magnitude of the benefits, experts have recommended that a change in practice favouring routine probiotic supplementation is justified if a safe and effective probiotic product is available.

Results of observational studies involving routine use of probiotic supplementation in preterm including extremely low birth weight (ELBW) neonates, and longterm follow-up support such recommendations. Evaluating the benefits and risks of live vs dead probiotics is an exciting area of research Evidence indicates that the action of probiotics could be a dual one. Live probiotics influence the gut flora and the immune response, whereas the dead cell components exert an anti-inflammatory response. Variable amounts of dead cells may thus explain the variation in response to live probiotics. Products with dead probiotics may have several advantages, including safety and a long shelf-life. 
Table II

Evidence: Probiotics in Preterm Neonates

\begin{tabular}{|c|c|c|c|c|c|}
\hline $\begin{array}{l}\text { Cochrane } \\
\cdot 16 \text { trials } \\
\cdot 2842 \text { babies } \\
\cdot \text { Updated till Nov } \\
2010 \\
\cdot \text { Inclusions: < } 37 \\
\text { wk and/ or } \\
<2500 \text { gm } \\
\cdot \text { Any pro biotic/ } \\
\text { variable dose x } 7 \\
\text { days vs placebo } \\
\text { or no treatment }\end{array}$ & $\begin{array}{l}\text { NEC 2/3 } \\
0.35(0.24-0.52) \\
{[65 \%} \\
\text { reduction] } \\
\text { NNT=25 } \\
\text { High quality } \\
\text { studies } \\
0.25(0.23-0.49) \\
{[75 \%} \\
\text { reduction] }\end{array}$ & $\begin{array}{l}\mathbf{N E C}<\mathbf{1 5 0 0} \\
0.34(0.23-0.50) \\
{[66 \% \text { reduction }]}\end{array}$ & $\begin{array}{l}\text { Morta lity } \\
0.40(0.27-0.600 \\
{[60 \% \text { reduction }]} \\
\text { NNT }=25 \\
\text { NEC reported } \\
\text { mortality } \\
0.31(0.10-0.94) \\
{[69 \% \text { reduction }]}\end{array}$ & $\begin{array}{l}\text { Sepsis } \\
0.90(0.76- \\
1.07)\end{array}$ & $\begin{array}{l}\text { Others } \\
\text { a. TPN days } \\
0.80(-0.30-1.90) \\
\text { b. Hospitalisation } \\
\text { days }-6.80(-7.08 \text { to } \\
-5.90) \\
\text { c. Weight gain } \\
0.28(-0.93,1.49) \\
\text { d. Time to full feeds } \\
-4.2(-4.8,-3.7) \\
\text { e. Long term } \\
\text { outcomes } \\
1.02(0.35-6.94)\end{array}$ \\
\hline $\begin{array}{l}\text { Walter }{ }^{\mathbf{5 3}} \\
\cdot 15 \text { RCTs } \\
\text { included } \\
\cdot 2764 \text { neonates } \\
\cdot \text { Up to date Nov } \\
2010 \\
\cdot \text { GA <37 wk or } \\
\text { BW < } 1500 \text { gm }\end{array}$ & \multicolumn{5}{|c|}{$\begin{array}{l}\text { Did subgroup analysis for different strains and found significant difference in NEC for } 5 \text { studies } \\
\text { and not rest } \\
\text { No difference in mortality and sepsis } \\
\text { Comments by Walter } \\
\text { - Non-inclusion of unpublished studies (b) Heterogeneity in studies (c)A considerable variety } \\
\text { of probiotics has been studied in preterm infants in RCTs } \quad \text { (d)Publication bias (e) Probiotic } \\
\text { therapy alone or probiotics in combination with bovine lactoferrin (f) blinding or not } \\
\text { blinding (g) definition of the primary outcome a priority or during the ongoing trial (h) } \\
\text { appropriate sample size calculation or not }\end{array}$} \\
\hline $\begin{array}{l}\text { Wang et al } \\
\text { Subgroup analysis } \\
\text { of Bifidiobacteria, } \\
\text { Lactobacilli, and } \\
\text { Bifidiobacteria + } \\
\text { Lactobacilli }\end{array}$ & $\begin{array}{l}0.33(0.24-0.46) \\
(20 \text { studies })\end{array}$ & $0.56(0.43-0.73)$ & $0.90(0.71-1.15)$ & & \\
\hline
\end{tabular}

Data is represented as RR (95\% CI) ; RR -relative risk, CI - confidence interval, NNT -number needed to treat, TPN- total parentral nutrition, GA- gestational age, BW- birth weight

\section{DISCUSSION}

Evidence of the beneficial effects of probiotics on human health is accumulating. There is support for routine introduction to prevent certain diseases in specific populations. For example, the Cochrane Neonatal Review Group states that current evidence for the use of probiotics to prevent NEC and all-cause mortality in preterm infants supports a change in practice ${ }^{35}$ (i.e. from non-routine to routine administration). Other authors and experts also advocate that probiotics should be a part of regular clinical practice, stating that 'current probiotics could prevent tens of thousands of deaths annually, and that 'further placebo-controlled trials are not warranted'. So, if there is emphatically favourable evidence for the routine use of probiotics in neonatology, why has practice not changed?

Other concerns have been raised regarding the generalisability of the results of published RCTs and reviews. Very few of the most vulnerable extremely low birth weight (below $1000 \mathrm{~g}$ ) and extremely low gestational age (below 28 weeks' gestation) infants, who are most at risk of morbidity and adverse out-comes, have been included in the RCTs or reviews, such that results from meta-analyses cannot be extrapolated to these infants. 
Table III

Future studies (results awaited)

\begin{tabular}{|l|l|l|l|l|}
\hline Study & $\begin{array}{l}\text { Primary } \\
\text { outcome }\end{array}$ & Inclusion criteria & Sample size & $\begin{array}{l}\text { Time of } \\
\text { completion }\end{array}$ \\
$\begin{array}{l}\text { Garland SM Proprem trial } \\
\text { (Australia, Newzeland) }\end{array}$ & LONS & $\begin{array}{l}<1500 \mathrm{~g} \\
\text { and }<32 \mathrm{wk}\end{array}$ & 1100 & March 2012 \\
\hline $\begin{array}{l}\text { Costeloe } \\
\text { PIP trial (UK) } 55\end{array}$ & $\begin{array}{l}\text { Sepsis, NEC, } \\
\text { death }\end{array}$ & $<31 \mathrm{wk}$ & 1300 & 2013 \\
\hline
\end{tabular}

LONS: late onset neonatal sepsis; NEC: necrotizing enterocolitis; ProPrem: Probiotics for premies; PIP: Probiotics in preterms

On the other hand, Deshpande et $a l^{36,48}$ described the use of probiotics as very favorable and commented that "The significant effect, size, precision, consistency, extremely low $\mathrm{p}$ values almost ruling out the role of chance alone, low risk of publication bias, no statistical heterogeneity, critical areas of benefit, all indicate that withholding probiotics from high-risk neonates is now almost unethical. Further he described that "It will be very difficult to justify the need for additional placebocontrolled trials". ${ }^{48}$

It is clear that there is great reason to be hopeful regarding the effect of probiotics. However, metaanalyses and multiple small trials have led us astray before and should not be over interpreted. The barrier to probiotics use is not in whether the neonatal community is convinced by the available data and believes that these drugs might be effective but in the need to have a more careful evaluation that addresses the optimum type of probiotics, the dosage, and multiple other factors such as their effect in ELBW and breastfed infants.

\section{CONCLUSION}

The evidence from clinical trials of probiotics in neonates is promising, particularly the use of probiotics to prevent NEC in preterm infants and atopic eczema in high-risk term infants. However, the current guidelines from the European Society for Pediatric Gastroenterology, Hepatology and Nutrition and the American Academy of Pediatrics state that there is insufficient evidence at this time to recommend routine administration to all neonates. ${ }^{56,57}$

\section{REFERENCES}

1. (FAO), F.a.A.O.o.t.U.N. Health and Nutritional Properties of Probiotics in Food including Powder Milk with Live Lactic Acid Bacteria. 2001.
2. Teitelbaum JE, Walker WA. Nutritional impact of pre- and probiotics as protective gastrointestinal organisms. Annu Rev Nutr 2002;22:107-38.

3. Hammerman C, Bin-Nun A, Kaplan M. Germ warfare: probiotics in defense of the premature gut. Clin Perinatol 2004;31(3):489500 .

4. Stratiki Z, Costalos C, Sevastiadou S, Kastanidou O, Skouroliakou M, Giakoumatou A, et al. The effect of a bifidobacter supplemented bovine milk on intestinal permeability of preterm infants. Early Hum Dev 2007;83(9):575-9.

5. Awad H, Mokhtar H, Imam SS, Gad GI, Hafez H, Aboushady $\mathrm{N}$. Comparison between killed and living probiotic usage versus placebo for the prevention of necrotizing enterocolitis and sepsis in neonates. Pak J Biol Sci 2010;13(6):253-62.

6. Rouge C, Piloquet H, Butel MJ, Berger B, Rochat F, Ferraris L, et al. Oral supplementation with probiotics in very-low-birthweight preterm infants: a randomized, double-blind, placebocontrolled trial. Am J Clin Nutr 2009;89(6):1828-35.

7. Neu J. Neonatal necrotizing enterocolitis: an update. Acta Paediatr Suppl 2005;94(449):100-5.

8. Guarner F, Malagelada JR. Gut flora in health and disease. Lancet 2003;361(9356):512-9

9. Stark PL, Lee A. The microbial ecology of the large bowel of breast-fed and formula-fed infants during the first year of life. J Med Microbiol 1982;15(2):189-203.

10. Yoshioka H, Iseki K, Fujita K. Development and differences of intestinal flora in the neonatal period in breast-fed and bottle-fed infants. Pediatrics 1983;72(3):317-21.

11. Kleessen B, Bunke H, Tovar K, Noack J, Sawatzki G. Influence of two infant formulas and human milk on the development of the fecal flora of newborn infants. Acta Paediatr 1995; 84 (12): 1347-56.

12. Balmer SE, Wharton BA. Diet and fecal flora in the newborn: breast milk and infant formula. Arch Dis Child 1989;64(12): 1672-7.

13. Harmsen HM, Wildeboer-veloo AC, Raangs GC, Wagendorp AA, Klijn N, Bindels JG, et al. Analysis of intestinal flora development in breast-fed and formula-fed infants by usingmolecular identification and detection methods. J Pediatr 
Gastroenterol Nutr 2000;30(1):61-7.

14. Commane DM, Shortt CT, Silvi S, Cresci A, Hughes RM, Rowland IR. Effects of fermentation products of pro- and prebiotics on trans-epithelial electrical resistance in an in vitro model of the colon. Nutr Cancer 2005;51(1):102-9.

15. Falony G, Vlachou A, Verbrugghe K, De Vuyst L. Cross-feeding between Bifidobacterium longum BB536 and acetate-converting, butyrate-producing colon bacteria during growth on oligofructose. Appl Environ Microbiol 2006;72(12):7835-41.

16. Bjorksten B, Naaber P, Sepp E, Mikelsaar M. The intestinal microflora in allergic Estonian and Swedish 2-year-old children. Clin Exp Allergy 1999;29(3):342-6.

17. Hickey L, Jacobs SE, Garland SM; ProPrems Study Group. Probiotics in neonatology. J Paediatr Child Health 2012;48(9):777-83.

18. Hooper LV, Midtvedt T, Gordon JI. How host-microbial interactions shape the nutrient environment of the mammalian intestine. Annu Rev Nutr 2002;22:283-307.

19. Turnbaugh PJ, Ley RE, Mahowald MA, Magrini V, Mardis ER, Gordon JI. An obesity-associated gut microbiome with increased capacity for energy harvest. Nature 2006;444(7122):1027-31.

20. Kamiya T, Wang L, Forsythe P, Goettsche G, Mao Y, Wang Y, et al. Inhibitory effects of Lactobacillus reuteri on visceral pain induced by colorectal distension in Sprague-Dawley rats. Gut 2006;55(2):191-6.

21. Eckburg PB, Bik EM, Bernstein CN, Purdom E, Sargent M, et al. Diversity of the human intestinal microbial flora. Science 2005;308(5728):1635-8.

22. Palmer C, Bik EM, DiGiulio DB, Relman DA, Brown PO. Development of the human infant intestinal microbiota. PLoS Biol 2007;5(7):e177.

23. Pietzak M. Bacterial colonization of the neonatal gut. J Pediatr Gastroenterol Nutr 2004; 38(4):389-91.

24. Seksik P, Sokol H, Lepage P, Vasquez N, Manichanh C, Mangin I, et al. Review article: the role of bacteria in onset and perpetuation of inflammatory bowel disease. Aliment Pharmacol The 2006;24(3):11-8.

25. Osborn DA, Sinn JK. Probiotics in infants for prevention of allergic disease and food hypersensitivity.Cochrane Database Syst. Rev. 2007;4: CD006475.

26. Schwiertz A, Gruhl B, Lobnitz M, Michel P, Radke M, Blaut M. Development of the intestinal bacterial composition in hospitalized preterm infants in comparison with breast-fed, fullterm infants. Pediatr Res 2003;54(3):393-9.

27. Cotton CM. Early, prolonged use of postnatal antibiotics increased the risk of necrotising enterocolitis. Arch Dis Child Educ Pract Ed 2010;95(3):94.

28. Wang Y, Hoenig JD, Malin KJ, Qamar S, Petrof EO, Sun J, et al. 16S rRNA gene-based analysis of fecal microbiota from preterm infants with and without necrotizing enterocolitis. ISME J 2009;3(8):944-54.

29. Mshvildadze M, Neu J, Shuster J, Theriaque D, Li N, Mai V. Intestinal microbial ecology in premature infants assessed with non-culture-based techniques. J Pediatr 2010;156(1): 20-5.
30. Magne F, Abely M, Boyer F, Morville P, Pochart P, Suau A. Low species diversity and high interindividual variability in faeces of preterm infants as revealed by sequences of $16 \mathrm{~S}$ rRNA genes and PCR-temporal temperature gradient gel electrophoresis profiles. FEMS Microbiol Ecol 2006;57(1):128-38.

31. Wang B, Mao YK, Diorio C, Pasyk M, Wu RY, Bienenstock J, et al. Luminal administration ex vivo of a live Lactobacillus species moderates mouse jejunal motility within minutes. FASEB J 2010;24(10):4078-88.

32. Ortiz-Andrellucchi A, Sánchez-Villegas A, Rodríguez-Gallego C, Lemes A, Molero T, Soria A, et al. Immunomodulatory effects of the intake of fermented milk with Lactobacillus casei DN114001 in lactating mothers and their children. Br J Nutr 2008; 100(4):834-45.

33. Prescott SL, Wickens K, Westcott L, Jung W, Currie H, Black $\mathrm{PN}$, et al. Supplementation with Lactobacillus rhamnosus or Bifidobacterium lactis probiotics in pregnancy increases cord blood interferon-gamma and breast milk transforming growth factor-beta and immunoglobin A detection. Clin Exp Allergy 2008;38(10):1606-14.

34. Manzoni P, Rinaldi M, Cattani S, Pugni L, Romeo MG, Messner H, et al. Bovine lactoferrin supplementation for prevention of late-onset sepsis in very low-birth-weight neonates: a randomized trial. JAMA 2009;302(13):1421-8.

35. Alfaleh K, Anabrees J, Bassler D, Al-Kharfi T. Probiotics for prevention of necrotizing enterocolitis in preterm infants. Cochrane Database Syst Rev 2011 16;(3): CD005496

36. Deshpande G, Rao S, Patole S, Bulsara M. Updated metaanalysis of probiotics for preventing necrotizing enterocolitis in preterm neonates. Pediatrics 2010;125(5):921-30.

37. Alfaleh K, Anabrees J, Bassler D. Probiotics reduce the risk of necrotizing enterocolitis in preterm infants: a meta-analysis. Neonatology 2010;97(2):93-9.

38. Srinivasjois R, Rao S, Patole S. Prebiotic supplementation of formula in preterm neonates: a systematic review and metaanalysis of randomised controlled trials. Clin Nutr 2009;28(3):237-42.

39. Barclay AR, Stenson B, Simpson JH, Weaver LT, Wilson DC. Probiotics for necrotizing enterocolitis: a systematic review. J Pediatr Gastroenterol Nutr 2007;45(5):569-76.

40. Guthmann F, Kluthe C, Buhrer C. Probiotics for prevention of necrotising enterocolitis: an updated meta-analysis. Klin Padiatr 2010;222(5):284-90.

41. Bell MJ, Ternberg JL, Feigin RD, Keating JP, Marshall R, Barton L, et al. Neonatal necrotizing enterocolitis. Therapeutic decisions based upon clinical staging. Ann Surg 1978; 187(1):1-7.

42. Indrio F, Riezzo G, Raimondi F, Bisceglia M, Cavallo L, Francavilla R. The effects of probiotics on feeding tolerance, bowel habits, and gastrointestinal motility in preterm newborns. J Pediatr 2008;152(6):801-6.

43. Braga TD, da Silva GA, de Lira PI, de Carvalho Lima M. Efficacy of Bifidobacterium breve and Lactobacillus casei oral supplementation on necrotizing enterocolitis in very-low-birthweight preterm infants: a double-blind, randomized, controlled trial. Am J Clin Nutr 2011;93(1):81-6. 
44. Mohan R, Koebnick C, Schildt J, Mueller M, Radke M, Blaut M. Effects of Bifidobacterium lactis Bb12 supplementation on body weight, fecal $\mathrm{pH}$, acetate, lactate, calprotectin, and IgA in preterm infants. Pediatr Res 2008;64(4):418-22.

45. Manzoni P, Lista G, Gallo E, Marangione P, Priolo C, Fontana $\mathrm{P}$, et al. Routine Lactobacillus rhamnosus $G G$ administration in VLBW infants: a retrospective, 6-year cohort study. Early Hum Dev 2011;87(Suppl1):S35-8.

46. Garland SM, Tobin JM, Pirotta M, Tabrizi SN, Opie G, Donath S, et al. The ProPrems trial: investigating the effects of probiotics on late onset sepsis in very preterm infants. BMC Infect Dis 2011;11:210.

47. Pelucchi C, Chatenoud L, Turati F, Galeone C, Moja L, Bach JF, et al. Probiotics supplementation during pregnancy or infancy for the prevention of atopic dermatitis: a meta-analysis. Epidemiology 2012;23(3):402-14.

48. Deshpande GC, Rao SC, Keil AD, Patole SK. Evidence-based guidelines for use of probiotics in preterm neonates. BMC Med 2011;9:92.

49. Kukkonen K, Kuitunen M, Haahtela T, Korpela R, Poussa T, Savilahti E. High intestinal IgA associates with reduced risk of IgE-associated allergic diseases. Pediatr Allergy Immunol 2010;21(1):67-73.

50. Penders J, Thijs C, van den Brandt PA, Kummeling I, Snijders B, Stelma F, et al. Gut microbiota composition and development of atopic manifestations in infancy: the KOALA Birth Cohort Study. Gut 2007;56(5):661-7.
51. Kalliomaki M, Salminen S, Arvilommi H, Kero P, Koskinen P, Isolauri E. Probiotics in primary prevention of atopic disease: a randomized placebo-controlled trial. Lancet 2001;357 (9262): 1076-9.

52. Osborn DA, Sinn JK. Probiotics in infants for prevention of allergic disease and food hypersensitivity. Cochrane Database Syst Rev 2007 17;(4):CD006474.

53. Mihatsch WA, Braegger CP, Decsi T, Kolacek S, Lanzinger H, Mayer B, et al. Critical systematic review of the level of evidence for routine use of probiotics for reduction of mortality and prevention of necrotizing enterocolitis and sepsis in preterm infants. Clin Nutr 2012;31(1):6-15.

54. Wang Q, Dong J, Zhu Y. Probiotic supplement reduces risk of necrotizing enterocolitis and mortality in preterm very low-birth-weight infants: an updated meta-analysis of 20 randomized, controlled trials. J Pediatr Surg 2012;47(1):241-8.

55. Millar M, Wilks M, Fleming P, Costeloe K. Should the use of probiotics in the preterm be routine? Arch Dis Child Fetal Neonatal Ed 2012;97(1):F70-4.

56. Thomas DW, Greer FR. Probiotics and prebiotics in pediatrics. Pediatrics 2010;126(6):1217-31.

57. Agostoni C, Buonocore G, Carnielli VP, De Curtis M, Darmaun $\mathrm{D}$, Decsi T, et al. Enteral nutrient supply for preterm infants: commentary from the European Society of Paediatric Gastroenterology, Hepatology and Nutrition Committee on Nutrition. J Pediatr Gastroenterol Nutr 2010;50(1):85-91. 